Culture \& Society: Journal of Anthropological Research

VOL. 1 NO. 2 DESEMBER 2019

http://culture.ppj.unp.ac.id

Email: culture@ppj.unp.ac.id

ISSN: 2686-343X (E-ISSN) 2686-3421 (P-ISSN)

DOI: https://doi.org/10.24036/culture/vol1-iss2/26

\title{
Pergeseran Hukum Waris Adat Di Minangkabau \\ (Studi Kasus: Hukum Warisan Tanah Ulayat \\ di Nagari Ladang Panjang Kecamatan Tigo Nagari, Kabupaten Pasaman, Sumatera Barat)
}

Eti Siska Putri ${ }^{1}$, Firman Firman ${ }^{2}$, Rusdinal Rusdinal ${ }^{3}$

${ }^{1}$ SMAN 1 Tigo Nagari Pasaman

${ }^{2,3}$ Universitas Negeri Padang

Email: etisiskaputri@gmail.com, firman@konselor.org, rusdinal@fip.unp.ac.id

\begin{abstract}
Suku bangsa Minangkabau dalam hukum adat mengenal dua macam harta yang diwariskan yaitu harta pusako tinggi, harta yang diwariskan dari mamak ke kemenakan sedangkan harta pusako randah pewarisan dari orang tua yang merupakan hasil matapencaharianya. Namun yang terjadi di Nagari Ladang Panjang bentuk warisan hukum adat tidak sesuai dengan hukum adat ulayat yang berlaku. Maka dari itu tujuan penelitian ini untuk mendeskripsikan bentuk pergeseran hukum waris adat dan menjelaskan factor-faktor terjadinya pergeseran hukum waris adat di Nagari Ladang Panjang, Kecamatan Tigo Nagari, Kabupaten Pasaman Sumatera Barat. Penelitian ini mengunakan pendekatan kualitatif dan tipe penelitian deskriptif. Teknik pemilihan informan dilakukan dengan cara purposive sampling. Teknik pengumpulan data dengan observasi, wawancara mendalam dan studi dokumen. Analisis data yang digunakan data interaktif dari Miles Huberman. Hasil penelitian menunjukkan bahwa bentuk pergeseran hukum waris adat di Nagari Ladang Panjang yaitu ganggam bauntuak, pamulang jariah payah, pagang-gadai dan jual beli. Factor-faktor pergeseran hukum waris adat di Nagari Ladang Panjang yang ditemukan di Nagari Ladang Panjang adalah diakibatkan oleh program Badan Pertanahan Nasional (BPN) yaitu prona (sertifikasi gratis). Kedua, ketidakpahaman masyarakat terhadap hukum adat pewarisan di Minangkabau. Ketiga Pemerintahan Nagari dan lembaga Kerapatan Adat Nagari (KAN) tidak menjalankan fungsinya dengan baik.
\end{abstract}

Keyword: Hukum Waris Adat, Hukum, Pergeseran

\section{Abstract}

Minangkabau tribe in customary law recognizes two kinds of inherited assets, namely "high pusako" property, assets inherited from Mamak to nephew while inheritance "pusako" property from parents who are the result of their livelihood. However, what happened in Nagari Ladang Panjang, the form of inheritance of customary, law is not by following the customary law in force. Therefore the purpose of this study is to describe the form of shifting customary inheritance law and explain the factors causing the shifting of customary inheritance law in Nagari Ladang Panjang, Tigo Nagari District, Pasaman Regency, West Sumatra. This study uses a qualitative approach and descriptive type of research. The informant selection technique is done by purposive sampling. Data collection techniques with observation, in-depth interviews, and document study. Analysis of the data used interactive data from Miles Huberman. The results showed that the form of shifting the customary inheritance law in Nagari Ladang Panjang, namely "ganggam bauntuak", "pamulang jariah" earned, pawn-selling, and buying and selling. The factors of shifting the customary inheritance law in Nagari Ladang Panjang found in Nagari Ladang Panjang were caused by the National Land Agency (BPN) program, namely prone (free certification). Second, the community's lack of understanding of customary inheritance law in Minangkabau. The three Nagari Governments and the Nagari Traditional Density Institution (KAN) did not function properly.

Keyword: Customary inheritance, Friction, Law

\begin{tabular}{l|l|l} 
Received: December 2, 2019 & Revised: December 29, 2019 & Published: December 31, 2019 \\
\hline
\end{tabular}

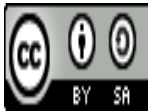

Culture \& Society: Journal of Anthropological Research Vol. 1, No. 2, Th. 2019 


\section{Pendahuluan}

Sistem pewarisan hukum warisan adat tanah ulayat di Minangkabau sangat berkaitan dengan ssitem Matrilinial yang diatur di hukum adat Minangkabau. Di dalam masyarakat Minangkabau pewarisan tanah ulayat diatur berdasarkan hukum Ibu seperti kekerabatan, keluarga, perceraian dan lainnya. Sesuai dengan aturan adat menurut hukum ibu, maka ahli waris menurut hukum adat Minangkabau ditarik dari garis ibu. Untuk menjadi ahli waris apabila ada harta warisan yang ditinggal atau diwariskan oleh nenek moyang terdahulu yang sudah meninggal. Maka yang menjadi pewarisnya adalah mamak kepala waris yaitu lelaki tertua dalam kaum dan pihak ibu sebagai hak olah atau hak pakai atas tanah ulayat (Febrianti, 2018)

Kontek hukum adat di Minangkabau mengenal dua bentuk kepemilikan terhadap tanah ulayat yang diwariskan yaitu harta pusako tinggi dan harta pusako randah. Harta pusako tinggi dan harta pusako randah ini merupakan milik bersama dari suatu kaum dalam masyarakat. Warisan tersebut berdasarkan atas pertalian darah dan diwarisi secara turun temurun dari nenek moyang terdahulu. harta tersebut di bawah pengelolaan mamak kepala waris (lelaki tertua dalam kuam). Proses pemindahan kekuasaan atas harta pusaka ini dari mamak kepada kemenakan dalam istilah adata dsiebut dengan harto pusako basalain. Menurut pemikiran Van Vallenhoven dalam Syahmunir menegaskan bahwa "tanah ulayat dapat berupa ulayat Nagari, ulayat suku, dan ulayat kaum sebagai harta pusaka tinggi, yang tidak boleh dipindah tangan selama-lamanya sangat terkait dengan fungsi tanah bagi kelangsungan hidupnya kaum dan suku Minangkabau" (Amir, 2015).

Pada dasarnya peralihan hak atas tanah dapat terjadi dalam bentuk umum yaitu, pertama, Penjualan, yaitu perpindahan hak atas tanah untuk selama-lamanya dengan menerima sejumlah uang yang dibayar tunai. Kedua, Pertukaran, yaitu perpindahan hak atas tanah untuk selamalamanya dengan mendapatkan penggantian tanah pada tempat yang berbeda letaknya. Ketiga, Penggadaian, yaitu perpindahan hak atas tanah untuk sementara waktu, dengan menerima sejumlah uang, tanah akan diperoleh kembali jika telah ditebus dengan sejumlah uang yang diterima dari pemegang gadai. Keempat, Hibah, yaitu pemberian tanah kepada seseorang, lembaga baik sementara atau selamanya. Kelima, Persewaan, yaitu perpindahan hak atas tanah untuk sementara waktu (sesuai jangka waktu yang ditentukan) dengan mendapatkan pembayaran berupa sewa (Herlynda, 2014)

Di Minangkabau untuk melakukan pemindahan hak atas tanah ulayat untuk selamanya tidak dibenarkan di dalam masyarakat Minangkabau karena hal itu sangat bertentangan dengan hkum adat di Minangkabau. Secara umum perpindahan hak ulayat di Minangkabau dikenal dengan bentuk sewa dengan istilah memperduai atau mempertigai (bagi hasil). Di Minangkabau untu mempertahankan warisan tanah ulayat maka ada jalan yang dibenarkan yaitu melakukan praktek pagang-gadai oleh masyarakat Minangkabau. Hal ini karena pelaksanaan pagang-gadai oleh masyarakat Minangkabau tidak akan menimbulkan kerugian pada salah satu pihak karena di dasari dengan kesepakatan berdua (Nugroho, Pudjiono \& Tohari, 2019)

Kenagarian Ladang Panjang adalah suatu nagari yang terletak dalam kecamatan Tigo Nagari, Kabupaten Pasaman. Sebagian besar masyarakatnya adalah petani, baik petani sawah ataupun berkebun. Tanah-tanah yang digarap pada umumnya adalah tanah ulayat yang diperoleh secara turun-temurun menurut garis keturunan ibu. Tata cara pemanfaatan dan kepemilikan tanah ulayat di Nagari Ladang Panjang menggunakan ketentuan hukum adat Minangkabau. Yang berhak memanfaatkan suatu tanah ulayat kaum adalah anggota kaum yang dapat dibuktikan dengan ranji. Peralihan pemanfaatan tanah ulayat kaum dapat terjadi karena perbuatan hukum yang dilakukan oleh salah satu anggota dalam kaum, namun perbuatan hukum itu harus disepakati terlebih dahulu dengan anggota kaum lainnya.

Berbanding terbalik dengan kenyataan di Nagari Ladang Panjang, Kecamatan Tigo Nagari yang merupakan masyarakat asli orang Minangkabau bahwa terdapat masyarakat dalam kaum yang memperjualbelikan tanah ulayat dari kaumnya ke luar kaumnya. Mamak kepala waris yang merupakan sebagai ahli untuk melakukan pengawasan terhadap harta pusaka tinggi sedangkan kaum perempuan sebagai hak olah pakai tanah ulayat namun yang ditemukan 
berdasarkan hasil wawancara dan observasi di lapangan bahwa masyarakat pada saat sekarang tidak ada rasa engan untuk memperjualbelikan harta pusaka tinggi tersebut. Hal itu peneliti temukan di beberapa Jorong yang merupakan sawah ladang yang diperjualbelikan anggota kaum yang menjual adalah pihak perempuan dan anggota laki-laki dalam kaum.

Adapun alasan peneliti untuk melakukan penelitian ini di karena melihat dari permasalahan yang ada di Nagari Ladang Panjang bahwa dilihat pada saat sekarang seirng berjalannya waktu pada saat sekarang kedudukan harta pusako tinggi tidak hanya digadaikan melainkan banyak cara masyarakat untuk melakukan pergeseran hukum hal ulayat tanah bahkan masyarakat di Nagari Ladang Panjang sudah ada yang melakukan jula beli harto pusako tinggi yang merupakan warisan dari nenek moyang mereka yang harus dipertahankan, hal itulah yang menjadi pertanyaan peneliti kenapa harta pusako tinggi ini diperjual belikan? apakah orang Minangkabau sudah tidak lagi menjunjung adat istiadat budaya Minangkabau yang dalam mempertahankan harta pusako tinggi. Apakah yang menjadi factor pendukung terjadinya pergeseran hukum waris adat di Minangkabau Atau mungkin masyarakat Minangkabau sudah melupakan adat istiadat Minangkabau yang mana harta pusako tinggi harus dijaga karena melihat dari kedudukan dari tanah ulayat Di Minangkabau. Dari berbagai penjelasan dan pertanyaan di atas penulis tertarik untuk mengangkat sebuah penelitian tentang "Pergeseran Hukum Waris Adat Minangkabau (studi: di Nagari Ladang Panjang, Kecamatan Tigo Nagari, Kabupaten Pasaman, Sumatera Barat)"

\section{Metode Penelitian}

Pendekatan yang digunakan dalam penelitian ini adalah pendekatan kualitatif dengan tipe deskriptif. Pendekatan kualitatif ini dikenal sebagai metode penelitian ilmu-ilmu social yang mengumpulkan dan menganalisis data berupa kata-kata dan perbuatan manusia serta tidak berusaha mengkuantifikasikan data (Afrizal, 2014). Dengan mengunakan pendekatan kualitatif ini dapat mengali secara mendalam mengenai pergeseran hukum warisan tanah ulayat di Minangkabau (studi: di Nagari Ladang Panjang, Kecamatan Tigo Nagari, Kabupaten Pasaman, Sumatera Barat).

Pemilihan Informan penelitian dengan mengunakan proposive sampling yaitu cara pemilihan informan penelitian dengan mengunakan criteria-kriteria sesuai dengan permasalahan penelitian (Sangadji, 2010). Criteria yang dimaksud dalam penelitian ini adalah orang-orang yang mengetahui dan yang terlibat menjual harto pusako tingi. Adapun informan dalam penelitian ini berjumlah 16 orang yang terdiri dari mamak kepala waris, tokoh masyarakat, patikan adat, masyarakat yang menjual harato pusako tinggi di Nagari Ladang Panjang. Pengumpulan data dilakukan dengan cara observasi, wawancara dan studi dokumentasi (Yusuf, 2005). Triangulasi data dengan membandingkan data dengan pengamatan dan hasil wawancara, serta membandingkan sumber data yang terkumpul dari sumber yang berbeda sedangkan untuk analisis data dalam penelitian ini mengunakan Miles dan Huberman (1984) mengemukaan bahwa aktifitas dalam analisis data kualitatif dilakukan secara interaktif dan berlangsung secara terus menerus sampai tuntas, sehingga datanya sudah jenuh". Teknik ini terdiri dari beberapa tahap yaitu reduksi data, penyajian data, dan penarikan kesimpulan (Sugiyono, 2012).

\section{Hasil dan Pembahasan}

\section{Bentuk Pergeseran Hukun Waris Adat Di Minangkabau}

Sistem adat Nagari Ladang Panjang yang berpedoman pada hukum adat Minangkabau yang mengatur dalam hukum waris tanah ulayat yaitu harto pusako tinggi. Pemangku jabatan Ketua Kerapat Adat Nagari (KAN) adalah seorang raja adat yang dipercayai dalam mengatur hukum waris adat di Nagari Ladang Panjang. Pengisian struktur adat Nagari Ladang Panjang dinamakan niniak mamak nan batujuah. Lembaga Kerapat Adat Nagari (KAN) beranggotakan penghulu suku/ninik mamak nan batujuah, Rajo-Rajo, alim ulama, cadiak pandai. Setiap Jorong di Nagari Ladang Panjang dikelolai oleh Rajo-rajo, sedangkan untuk Kaum dikepelai oleh Mamak Kepala Waris. 
Kewenangan subjek hak atas tanah adat/ulayat di Kenagarian Ladang Panjang diketahui bahwa terdapat empat kewenangan, yaitu hak perorangan, hak kaum, hak suku, dan hak nagari. Hak kewenangan perorangan terdiri dari hak untuk memungut hasil dan mengolah tanah, hak gadai dan hak memindahkan dengan pengembalian jariah payah. Hak kaum, sama dengan hak hak perorangan memungut dan mengolah tanah yang dilakukan bergantian oleh anggota kaum, hak gadai dan memungut hak sewa terhadap tanah. Hak dan kewenangan suku adalah hak mengolah dan mengambil hasil dari tanah tersebut serta melakukan pengawasan terhadap penggunaan hak perorangan dan kaum. Sementara khusus untuk hak dan kewenangan Nagari bentuk Hak ini sudah tidak ditemukan lagi di Nagari Ladang Panjang karena berdasarkan temuan penelitian bahwa Nagari Ladang Panjang tidak memiliki Tanah Ulayat Nagari yang bisa dimanfaatkan.

Dari hasil penelitian menunjukan bahwa bentuk tanah ulayat yang terdapat di Kenagarian Ladang Panjang saat ini hanya terdapat ulayat suku dan ulayat kaum. Tanah ulayat suku dan tanah ulayat kaum ini sama-sama disebut dengan harta pusako tinggi yang membedakannya hanyalah subjek penguasaan. Jika suatu suku memiliki kaum maka tanggung jawab penguasaannya berada pada mamak kepala waris dari kaum tersebut. Jika penguasaan terhadap objek langsung oleh Penghulu Suku, maka objek tersebut adalah ulayat suku dan tanggung jawab penguasaan ulayat suku tersebut langsung kepada Penghulu Suku.

Menurut Bapak Bahron sebagai Rajo Bangkeh menyatakan bahwa adat Nagari Ladang Panjang untuk penguasaan tanah ulayat hanya sebatas hak untuk mengolah dan memetik hasil serta menggunakan tanah adat tersebut. Penguasaan terhadap ulayat tergantung kepada status dari ulayat itu sendiri. Ulayat suku maka merupakan hak mutlak suku tersebut untuk menguasai. Ulayat kaum dikelola oleh kaum dan atas pengawasan mamak kepala waris yaitu lelaku tetuan di dalam Kaum.

Di Minangkabau Peralihan kepemilikan tanah pada zaman dahulu tidak pernah terjadi yang ada hanya peralihan dalam penguasaan sementara akan tetapi pada zaman sekarang anggota kaum ingin menggarap dan menguasai tanah itu bebas dari pengaruh anggota kaum lain, apakah tanah itu akan dijual, di gadai, atau dimanfaatkan sendiri. Disamping itu pada zaman sekarang orang tidak akan mau untuk menyewa apalagi membeli tanah tanpa sertifikat sebagai suatu bukti kepemilikan yang sah. Pada masing-masing hak atas tanah yang terdapat di Minangkabau akan terlihat hubungan timbal balik yang saling mengisi antara yang satu dengan yang lainnya. Hal ini dapat dilihat dengan adanya perubahan dari status tanah dengan intensifnya penguasaan hak atas tanah oleh masyarakat di Minangkabau. Sebagaimana dikemukakan oleh Bushar Muhamad, bahwa hubungan interaksi antara hak ulayat dan individu satu sama lainnya adalah dalam keadaan mengembang dan mengempis tergantung pada intensitas penggarapan atau pengelolaan individu.

Di Nagari Ladang Panjang terdapat beberapa bentuk pergeseran hukum adat tanah ulayat yaitu:

\section{Ganggam Bauntuak}

Berdasarkan hasil wawancara dengan Bapak Ali bahwa "bentuk penguasaan terhadap tanah ulayat oleh anggota kaum yang telah disepakati oleh seluruh anggota kaum di Nagari Ladang Panjang. Perpindahan penguasaan pada nganggam bauntuak terjadi ketika ulayat kaum diberikan kepada salah satu anggota dalam kaum. Namun tidak mengubah status terhadap tanah ulayat kaum. Pemegang hak ngaanggam bauntuak tidak dapat mengalihkan hak penguasaan terhadap tanah yang dikuasainya secara sendiri, seperti melakukan gadai atau melakukan pengembalian jariah payah. Jika gadai atau jariah payah dilakukan terhadap tanah ulayat kaum maka harus dilakukan atas persetujuan seluruh anggota kaum.

\section{Pamulang Jariah Payah}

Menurut adat Nagari Ladang Panjang pengembalian pamulang jariah payah adalah bentuk peralihan penguasaan terhadap tanah ulayat oleh pemangku hak sebelumnya kepada anggota kaum lainnya dengan syarat mengembalikan segala bentuk jasa yang telah dikeluarkan oleh si pemangku hak tanah sebelumnya. Di Nagari Ladang Panjang berdasarkan temuan

\section{Culture \& Society: Journal of Anthropological Research Vol. 1, No. 2, Th. 2019}


bahwa tanah ulayat kaum yang sudah tanaman pohon pinang dan pohon kelapa oleh pemangku hak sebelumnya, maka sipemangku hak berikutnya harus membayar jariah payah tersebut sesuai dengan nilai yang dikeluarkan. Perbuatan hukum pamulang Jariah payah ini pada hakikatnya adalah menganti jariah payah orang atau nenek moyang yang manaruko (membuka) tanah ulayat tersebut.

\section{Salang-pasalang tanah ulayat kaum (gadai tanah kaum)}

Gadai adalah bentuk peralihan penguasaan atau pemanfaatan terhadap tanah ulayat dari anggota suku yang satu ke anggota suku yang lain. Gadai dapat dilakukan kepada anggota suku atau kaum lainnya atau kepada pihak luar di luar anggota suku atau kaum. Namun, sebagaimana yang telah Penulis sampaikan pada bagian sebelumnya. Kalau ada tanah ulayat tergadai, maka yang tergadai bukanlah tanahnya, tetapi adalah hak pengelolaannya. Adat di Minangkabau, di Kenagarian Ladang Panjang juga mengenal beberapa syarat gadai yaitu Rumah gadang katirisan, Maik tabujua di ateh rumah, Gadih gadang indak balaki, dan Mambangkik batang tarandam.

Namun, tidak sama halnya dengan apa yang terjadi di kenagarian Ladang Panjang bahwa gadai atau salang pasalang dilakukan memiliki nilai yang sangat tinggi yang mana tanah yang digadaikan merupakan milik kaum namun ada di dalam kaum yang mengadaikan tanah ulayat kaum dengan nilai uang yang sangat tinggi sudah hamper dengan harga tanah tersebut. Hal itu membuat tanah ulayat kaum yang ada dalam suatu kaum hilang dari suatu kaum tersebut karena anggota dalam kaum tidak mampu untuk mengembalikan uang gadai yang sudah dilakukan oleh satu anggota kaum.

\section{Jual beli}

Masyarakat pada saat ini tidak lagi memahami adat Minangkabau terkait dengan adat hukum tanah di Minangkabau, hal itu terbukti dengan hasil temuan dilapangan bahwa masyarakat di Kenagarian Ladang panjang sudah banyak kehilanagan tanah ulayat kaum yang merupakan harto pusako tinggi dalam suatu kaum karena banyak anggota dari kaum melakukan jual beli tanah kaum (karto pusako tersebut). Tanah ulayat kaum yang merupakan milik bersama dalam satu kaum yang wajib dijaga oleh angggota kaum namun yang terjadi di nagari lading panjang sawah yang terletak di Pasar Ladang Panjang milik kaum Cupak yang di perjualbelikan kepada pendatang tanpa melakukan prosedur yang sudah ditentukan dalam adat Minangkabau bahwa ketika hendak melakukan pergeserah hak ulayat tanah kaum itu dengan melalui musyawarah namun yang terjadi anggota kaum Cupak ini tidak melakukan musyawah dalam melakukan jual beli. Di Minangkabu pun tidak membenarkan untuk jual beli harto pusako karena sangat bernilai tinggi dalam suatu kaum, wibawa dalam suatu kaum akan memiliki stratifikasi tinggi ketika mereka memiliki tanah yang luas namun dilihat pada saat sekarang pepatah adat Minangkabau terkait dengan hukum hak ulayat tidak dipedulikan lagi oleh masyarakat.

\section{Faktor pendukung terjadinya pergeseran hukum hak ulayat tanah adat di Nagari Ladang Panjang}

Berdasarkan temuan dari hasil penelitian di Nagari Ladang Panjang bahwa adanya faktor pendukung atau yang menyebabkan "punahnya" tanah ulayat atau tingginya peralihan hak atas tanah ulayat di Kenagarian Ladang Panjang.

\section{Program Badan Pertanahan Nasional}

Sebagaimana yang telah Penulis sampaikan pada bagian sebelumnya, bahwa pergeseran hukum waris adat tanah di Jorong Kajai slaah satunya disebabkan oleh oleh program Badan Pertanahan Nasional (BPN) yaitu prona (sertifikasi gratis). Pada kesempatan itu dimanfaatkan oleh masyarakat Jorong Kajai untuk mensertifikat tanah yang merupakan tanah ulayat kaum yang dijadikan sebagai tanah pribadi di Minangkabau di istilahkan dengan harto pusako randah. Sehingga dengan hal tersebut hak ulayat yang pada mulanya milik anggota kaum namun setelah

Culture \& Society: Journal of Anthropological Research Vol. 1, No. 2, Th. 2019 
di dukung program badan pertanahan nasional tersebut hak ulayat tanah kaum tersebut bergeser menjadi milik pribadi.

\section{Ketidakpahaman Masyarakat Nagari Ladang Panjang Hukum Adat Tanah}

Berdasarkan hasil wawancara dengan informan penelitian yang menyatakan bahwa banyak pada masyarakat sekarang yang tidak memahami hukum adat tanah di Minangkabau. Berbicara mengenai tanah di Minangkabau maka hal itu sangat sacral dalam masyarakat karena kedudukan dari tanah ulayat sangat tinggi, hal itu dalam artian masyarakat Minangkabau pada dulunya sellau mempertahan warisan dari nenek moyang mereka yaitu tanah ulayat kaum hal itu disebabkan karena pengetahuan masyarakat terkait dengan hukum adat Minangkabau sangat diperhatikan namun pada saat sekarang pemahaman dan pengetahuan masyarakat kurang tentang hukum adat tanah di Minangkabau. Sehingga hal itu memmudahkan masyarakat untuk melakukan pergeseran hukum waris adat di Jorong Kajai. Hukum adat Minangkabau terutama tanah sebagai identitas adat. Masyarakat tidak memahami bahwa tanah ulayat menurut adat Minangkabau tidak dapat dialihkan haknya, terutama dalam bentuk jual beli.

\section{Pemerintahan Nagari dan lembaga Kerapatan Adat Nagari (KAN)}

Sebagai institusi yang secara moral harusnya bertanggung jawab menjaga keberadaan adat Minangkabau, tidak menjalankan fungsinya dengan baik. Banyak kasus yang ditemukan di Kenagarian Pungasan dan Air Haji, bahwa KAN dan perangkat pemerintahan nagari lainnya menjadi aktor utama ,punahnya"e ulayat nagari. kewenangan yang dimiliki Pemerintah Nagari dan KAN dalam mengeluarkan beberapa surat terhadap status suatu objek tanah, kemudian menjadi legitimasi bahwa suatu objek tanah ulayat bukan suatu tanah ulayat. Misalkan kewenangan KAN dan Wali Nagari untuk membuat suatu surat pernyataan dan menyatakan pada surat sporadik tentang status suatu tanah di wilayah administrasinya, apakah tanah ulayat atau bukan. Dalam kondisi negatif hal tersebut dapat mendorong punahnya tanah ulayat.

Adanya praktik-praktik tersebut kemudian mengakibatkan ketidakpercayaan masyarakat terhadap perangkat-perangkat pemerintahan nagari maupun Lembaga Kerapatan Adat Nagari (KAN) dalam menyelesaikan sengketa pusako. ketidakpercayaan masyarakat terhadap Kerapatan Adat Nagari dalam menyelesaikan sengketa pusako, atau sengketa mengenai hak terhadap tanah ulayat, menjadikan masyarakat adat lebih memilih untuk menempuh jalur hukum formal melalui gugatan di Pengadilan Negeri. Berdasrkan hasil temuan dari penelitian yang telah dilakukan sejak tahun 2017 hingga pada tahun 2019 di kenagarian Ladang Panjang ini sering terjadi konflik tanah ulayat akibat kewenangan Kerapatan Adat Nagari dalam menerbitkan surat Keputusan tentang kepemilikan objek tanah ulayat kaum di Kenagarian Ladang Panjang.

\section{Kesimpulan}

Berdasarkan hasil temuan dalam penelitian ini dapat kita simpulkan bahwa di Nagari Ladang Panjang asli orang Minangkabau yang terikat pada hukum adat tanah ulayat di Minangkabau. Pada hakikatnya masyarakat Minangkabau enggan untuk melakukan peralihan hak ulayat apalagi itu harta pusako tinggi namun yang terjadi di Nagari Ladang panjang terdapat beberapa bentuk pergeseran hukum hak ulayat tanah harto pusako tinggi dalam kaum yaitu ganggam bauntuak, pamulang jariah payah, pagang-gadai dan jual beli, ini merupakan salah satu factor yang menyebabkan hilangnya harta pusako dalam satu kaum yang merupakan warisan dari nenek moyang yang harus dijaga.

Faktor pendukung atau pendorong terjadinya pergeseran hukum hak tanah ulayat harta pusako tinggi terhadap tanah adat/ulayat di Kenagarian Ladang panjang adalah Pertama, diakibatkan oleh program Badan Pertanahan Nasional (BPN) yaitu prona (sertifikasi gratis). Kedua, ketidakpahaman masyarakat adat saat ini terhadap hukum adat Minangkabau terutama tanah sebagai identitas adat. Ketiga bahwa Pemerintahan Nagari dan lembaga Kerapatan Adat Nagari (KAN) sebagai institusi yang secara moral harusnya bertanggungjawab menjaga keberadaan adat Minangkabau namun mereka tidak menjalankan fungsinya dengan baik.

Culture \& Society: Journal of Anthropological Research Vol. 1, No. 2, Th. 2019 


\section{Daftar Pustaka}

Afrizal. (2014). Metode Penelitian Kualitatif(Jakarta). Rajawali Pers.

Amir, R. (2015). Gadai Tanah Perspektif Ekonomi Islam. Jurnal Muamalah, 5(1), 81-90.

Asmara, Galang \& Maladi, Y. (2012). Penyelesaian Konflik Pertanahan Berbasis Nilai-Nilai Kearifan Lokal Di Nusa Tenggara Barat. Mimbar Hukum, 22(1), 1-17. Https://Doi.Org/10.22146/Jmh.16215

Darmawan \& Abidin. (2017). Pemetaan Konflik Sosial Masyarakat Di Aceh Selatan (Studi Deskriptif Konflik Sosial Masyarakat Di Mukim Alue Paku Kecamatan Sawang). 1(1), 31-39.

Fauzan, M. (2014). Model Kerjasama Antar Sengketa Kewenangan Pada Daerah Kabupaten / Kota. Jurnal Media Hukum, 21(2), 197-212.

Febrianti, N. (2018). Implementasi Hukum Waris Minangkabau Pada Minang Perantau (Studi Pada Ikatan Keluarga Minang Kota Depok). Civics, 3(1), 1-15.

Herlynda, H. (2014). Peralihan Hak Atas Tanah Menurut Masyarakat Adat Di Kecamatan Linggo Sari Baganti Kabupaten Pesisir Selatan.

Hidayati, D. (2016). Memudarnya Nilai Kearifan Lokal Masyarakat Dalam Pengelolaan Sumber Daya Air (Waning Value Of Local Wisdom In The Management Of Water Resources ). 11(1), 39-48.

Nugroho, S. S., Pudjiono, M. J., \& Tohari, M. (2019). Hukum Tanah: Konstruksi Hukum Penyelesaian Sengketa Gadai Tanah Berbasis Hukum Adat Di Kabupaten Ngawi. 3(2), 26-34.

Sangadji, E. M. (2010). Metodologi Penenlitian. Yogjakarta: Cv Andi Offset.

Sugiyono. (2012). Metode Penelitian Pendidikan Kuantitatif, Kualitatif Dan R\&D. Bandung: Alfabeta.

Yusuf, A. M. (2005). Metodologi Penelitian. Padang: UNP Press. 